\title{
Privatization of medical education in India: A health system dilemma
}

\section{Sanjeev Davey, Anuradha Davey', Ankur Srivastava', Parul Sharma ${ }^{1}$}

Department of Community Medicine, Muzaffarnagar Medical College and Hospital, Muzaffarnagar, ${ }^{1}$ Department of Community Medicine, Subharti Medical College, Meerut,

Uttar Pradesh, India

Address for the Correspondence:

Dr. Sanjeev Davey,

B-197, $3^{\text {rd }}$ Floor, Prashant Vihar, Sector 14 Rohini, Delhi - 110 085, India.

E-mail: Sanjeevdavey333@ gmail.

com

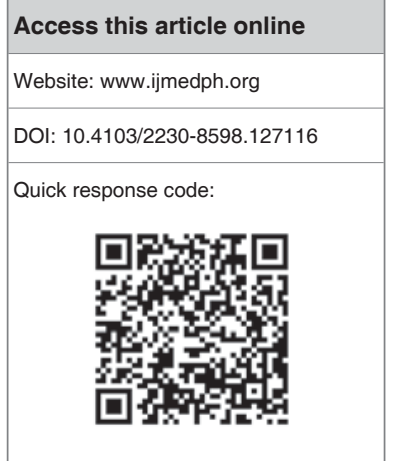

Background: Privatization of medical education can widen its scope and availability via creation of large no of medical professionals in allopathic system for Indian people, but can it be an alternative to create human resources with appropriate skill mix, especially when services in health system involves lives of the human being needs rethinking on an urgent basis. Objectives: To review the issues related with privatization of medical education system of India. Materials and Methods: A systematic review on key search word: "Privatization of medical Education in India" was done from main indexed journals of key medical search engines i.e. Pubmed, Cochrane, Bio-med Central, and Google Scholar etc. in all forms including e-journals till $15^{\text {th }}$ August 2013 since last 20 years. Conclusions: Indian allopathic medical education system is one of the largest in the world. Medical Colleges in India have rapidly progressed in last 25 years, especially in private set ups; there is no doubt that they can help Indian health care system, but the need of hour is, to critically look at the quality of students opting M.B.B.S course, quality of medical faculties in terms of their skill mix for clinical as well as para-clinical services, and quality of medical education imparted by these institutions, which can be achieved by strict implementation of strict Medical Council of India ( $\mathrm{MCl}$ ) norms, in order to ultimately improve the health care system of India in long run.

Key words: Health system, medical council of India, medical education, privatization

\section{INTRODUCTION}

\section{Current scenario of doctor-population ratio: Impact on Indian health care system}

According to World Health Organization (WHO) report, India ranks $67^{\text {th }}$ in the list of 133 developing countries with a doctor-population ratio at 1:1700 as compared to a world average of $1.5: 1000 .^{[1]}$ That means, not even 1 doctor is available for 1000 population, even after more than half century of independence; a goal still far behind as per the recommendation given by Bhore committee in 1946, subsequently modified by Mudaliar committee (1961) and Bajaj committee in 1987. Although WHO is aiming to achieve a doctor-population ratio of 1:1000, India can achieve this in 2031 within the framework of existing colleges and state of affairs. ${ }^{[1]}$ It is now also estimated that there will be still a shortage of 9.54 lakh doctors by the time India achieves that.

If we look at the achievement in health outcomes in Indian set up since independence, such as Maternal Mortality Ratio (MMR), Infant Mortality Rate (IMR), coverage with preventive and promotive interventions are found to be directly related to their human resource density. ${ }^{[2]}$ The Bajaj Committee (1986) had also recommended for the establishment of University of Health Sciences in states and group of Union Territories to award degrees and diplomas in health sciences for better health outcomes. ${ }^{[3]} \mathrm{A}$ few states have already established University of Health Sciences (Tamil Nadu, Karnataka, Maharashtra etc.) and so, they are now showing better health indicators.

In the last 2 decades, there has been a massive increase in the privatization of medical education with rapid expansion in the number of private medical colleges in India along with a boom in private medical education worldwide. These private medical colleges are either autonomous or partially autonomous. Though India has several private medical colleges and produces thousands of medical graduates now every year, still there is a great shortage of doctors in the rural areas. Most of these private medical graduates do not like to practice in rural areas. Factors like inadequate training, technical 
skill of the health force, improper deployment, inefficient skill mix, poor working environment, and lack of opportunities for personnel management are few reasons making the medical education system a more paradox to solve by our policy makers and implementers. ${ }^{[2]}$ Although Medical Council of India (MCI) - a regulator of medical education in India, role is to provide quality medical care to all Indians through promotion and maintenance of excellence in medical education both in private and government medical colleges and for that their website is also maintaining an up to date list. ${ }^{[4]}$ But, what we require is outcome of these private medical colleges for Indian public health system by strict monitoring and evaluation of these medical colleges by MCI on a frequent basis. In this article, therefore, authors with these problems in mind have reviewed the role of private medical colleges of India for Indian health care system.

\section{OBJECTIVES}

To critically review the issues related with privatization of medical education system of India.

\section{MATERIALS AND METHODS}

A systematic review on key search word: "Privatization of medical Education in India" was done from main indexed journals in key search engines i.e. Pubmed, Cochrane, Bio-med Central, and Google Scholar etc. in all forms including e-journals till $15^{\text {th }}$ August 2013 since last 20 years. Study Designs: Previous systematic reviews and all kinds of exploratory research studies on role of Privatization of medical Education in India were the main study designs, which were incorporated in any language and of any size and to any extent in shaping our research. Inclusion Criteria: From 70 articles, which were searched in above duration of 20 years, 37 articles met the inclusion criteria; both kinds of studies explaining good effects of privatization of medical education and bad effects of privatization of medical education were included in review. Criteria of impact, effectiveness, and evaluation of Privatization of medical Education in India was taken in search. Studies from both developed and developing world were also included including any conferences data, research reports, and research studies to draw final conclusions. Exclusion criteria: Unpublished data from Thesis/ Dissertation was not taken on both these reviews.

\section{DISCUSSION}

\section{Why need for privatization of medical education in India?}

Privatization is an act of reducing the role of government or increasing the role of the private institutions of society in satisfying people's needs; it means relying more on the private sector and less on government. ${ }^{[5]}$ Privatization of medical education can be defined as "Medical Education which is imparted by an organization, which is not a government part. They can be profit-generating institutions or non-profit societycentered institutions. ${ }^{\prime \prime 6}$ In 1951 after independence, there was 1 medical seat in government medical college for every 71,000 population. With sustained investments in medical education, the ratio has grossly gone down to 37,000 for every government medical seat in 1966 . Since then, situation has worsened due to continued negligence by the government for over 3 decades with 1 government medical college seat for every 55,000 population..$^{[7]}$

In order to establish an integrated network of evenly spread specialty and super specialty services, National Health Policy (2002) advocated to increase the availability and coverage of the health services by encouraging private investments. ${ }^{[8]}$ The National Rural Health Mission (NRHM) has also envisaged the participation of the private sectors to ensure that states make full use of the health care providers available in the remote areas, and to also encourage better utilization of the public-owned health facilities. ${ }^{[8]}$

In that order, Government of India (GOI) offered number of financial concessions to corporate hospitals in the form of the subsidized sale of the land, reduced import duties, and tax concession for medical research/medical education. (Baru 2000) $)^{[9]}$ Chakraborty (2003) has also mentioned that private sector can be encouraged in the health sector by providing utility charges, discounted and free land, and low interest land. ${ }^{[10]}$

\section{What is the current status of private medical colleges in India?}

India has witnessed rapid growth in the medical education sectors, as India tops the world with the largest numbers of medical colleges in world with a figure of 356, and out of these, about 162 are owned by government institutions and 194 by private management. ${ }^{[4]}$ Businessmen have now found this as a new avenue to make large earnings from private medical schools in the form of high tuition fees and high donations, ${ }^{[1]}$ putting the element of commercialization of the medical education to the serious note. In one of the article published in Times of India (TOI) dated $5^{\text {th }}$ Aug 2013, medical education in India is much costlier than its neighboring countries. ${ }^{[12]}$ As data available with the Medical Council of India, availability of the medical seats has improved in recent years. Almost half (47\%) of the available medical seats has been created since 2000 . However, over $72 \%$ of the seats added after 1972 are in private sector. ${ }^{[7]}$ Certain political events are also transforming the Indian medical education system; some of them are: Dissolution of MCI after the arrest of MCI president under charges of corruption, Clearance of new bill by Parliament of India, Prohibition of the Technical Education Institutions, Medical Education Institutions, and Universities Bill, 2010, Promotion of Public Private Partnership (PPP) in Medical education, and relaxation of norms for the same. ${ }^{[13]}$

In this context, landmark judgment was given by the Delhi High Court on Oct, 2011. Though it has emphasized the favorable role of private medical education system to bridge the gap between the number of doctors available and the India's teeming millions and mentioned it as need of the hour. At the same time, court has also mentioned clearly that administration has to be cautioned regarding the declining standards of medical education as well as 
money involved in charging higher fees. Therefore, court has given direction that there must be stringent conditions for monitoring the quality of medical education so that the trust of the common man in the custodians of our health is rejuvenated and strengthened. ${ }^{[14]}$

\section{Current scenario of private medical colleges from South India}

Over half of the private sector seats are concentrated in just 4 statesTamil Nadu, Kerala, Karnataka, and Andhra Pradesh, though they account for $21 \%$ of the India's population. In Karnataka, for every government seat, there are almost 4 private medical seats, while in Kerala, there are 2 private seats for every government medical seat. ${ }^{[7]}$ Nearly $60 \%$ of the medical colleges in India are located in 6 states, namely Andhra Pradesh, Tamil Nadu, Maharashtra, Karnataka, Kerala, and Pondicherry, and they have a doctor-population ratio of $1924,1165,1179,1457,7213$, and 994, respectively, as compared to all India figure of 5755 and 15438 in UP etc. [Table 1]. ${ }^{[15,16]}$ Stateswise distribution also clearly reveals the acute shortage of medical colleges in Uttar Pradesh, Rajasthan, Madhya Pradesh, Orissa, and Chhattisgarh, the all underperforming states according to health indicators of India. It shows significant geographical disparity in the distribution of the health workers across the states. As a rule, larger and poorer the states of Northern and Central India have lower density of the health worker when compared to the Southern States. The total number of the health workers per 10,000 population varies from 10 in Bihar to over 40 in Goa (Rao et al. 2009). ${ }^{[17]}$

\section{Private medical colleges in India: Will they really help?}

Encouragement of the privatization of the health system has been argued by Narayan (2003) that in Andhra Pradesh, private sector has outgrown the public sector through direct and indirect patronage of the state government. Private corporate hospitals receive huge amounts of public funds in the form of reimbursements from public sector undertaking and state and central government for treating their employees. That is, private segment has a possibility of replacing rather than complementing the public sector by weaning away the resources from the government. ${ }^{[18]}$

\section{Issue of qualified faculties}

Nearly 70 teachers are required per college for 50 admissions, 90 for more than 50 to 100 admissions, and 125 for 150 admissions per year as per MCI norms. This manpower requirement is only for the MBBS curriculum. ${ }^{[19]}$ Now real challenge is the availability of the medical trained faculties. Senior faculties who are mainly retired or on leave from government are appointed in the private sector. In this way, government has opinion that faculties crisis can be solved in these medical college. But, how much do they give their services on regular basis is a big question mark in terms of quality of medical education.

One of the emerging challenges in this area is also the issue of paper faculty for the sake of inspection purposes by MCI to get its approval. To check the regularity of the medical faculties, The Honb'le Supreme Court and executive committee of the MCI decided to prepare Radio Frequency Identification (RFID)-based Access Control Smart ID Cards for the faculties of medical colleges to check the problem of double employment in a single academic year and to avoid teachers with unrecognized postgraduate qualification getting employed as teachers. ${ }^{[20]}$ In the era of IT technology, it could have proved as an important instrument to help the MCI office at nodal point to check and verify the teacher's regular attendance as well as appointment of the qualified teachers as per MCI norms. But, ideas need strict implementation under the enforcement of MCI itself, rather than giving the edge of advantage to the management of many private medical colleges. Moreover, some of these private medical colleges also deny experience/ relieving certificates to assistant/associate professors, when they want to leave their institutions, this issue is also decreasing motivation for faculties joining private medical colleges.

To verify the teaching faculty, residents, and clinical material Pursuant to order of Hon'ble M.P. High Court, MCI conducted Inspection on $2^{\text {nd }}$ January, 2009, of 4 private medical colleges. They observed - the shortage of teaching faculty was about $60 \%$ and that of residents were $65 \%$. Clinical material was grossly inadequate as reported by the MCI inspectors. O.P.D. attendance was $20 \%$; bed

\begin{tabular}{|c|c|c|c|c|c|c|}
\hline States/UTs & $\begin{array}{l}\text { Population march } \\
\left.2008 \text { (in ' } 000^{\prime}\right)^{*}\end{array}$ & $\begin{array}{l}\text { Medical colleges } \\
\text { required @ } 1 \text { per } 50 \\
\text { lakh Population }\end{array}$ & $\begin{array}{l}\text { Existing no. of } \\
\text { medical colleges } \\
\text { (Govt./ Pvt.) }\end{array}$ & $\begin{array}{l}\text { Difference between } \\
\text { existing and required } \\
\text { number }\end{array}$ & $\begin{array}{l}\text { Current population } \\
\text { per medical college } \\
\text { (in '000') }\end{array}$ & $\begin{array}{l}\text { Total no. of } \\
\text { MBBS seats }\end{array}$ \\
\hline Andhra Pradesh & 82180 & 16 & 32 & +16 & 2568 & 4225 \\
\hline Karnataka & 57399 & 11 & 39 & +25 & 1472 & 4755 \\
\hline Tamil Nadu & 66396 & 13 & 25 & +12 & 2656 & 2865 \\
\hline Kerala & 34232 & 7 & 18 & +11 & 1902 & 2100 \\
\hline Maharashtra & 106894 & 21 & 40 & +19 & 2672 & 4560 \\
\hline Pondicherry & 1074 & $0(1)$ & 8 & +7 & 134 & 975 \\
\hline Bihar & 93823 & 18 & 8 & -10 & 11728 & 510 \\
\hline Madhya Pradesh & 69279 & 13 & 9 & -4 & 7698 & 1120 \\
\hline Rajasthan & 64641 & 13 & 8 & -5 & 8080 & 850 \\
\hline Uttar Pradesh & 190891 & 37 & 16 & -21 & 11931 & 1712 \\
\hline West Bengal & 87869 & 17 & 9 & -8 & 9763 & 1105 \\
\hline
\end{tabular}

*Projected population by Registrar General of India. Number of existing medical colleges and number of MBBS seats are taken from MCI website. 
occupancy was $30 \%$ as against $80 \%$ as per MCI norms of minimum requirements. ${ }^{[21]}$ Budding of private medical colleges in India on one side with severe shortage of medical faculty is actually creating the paradox in the situation.

\section{Issue of quality of medical students entering health care system and becoming health care provider}

For a government medical college, the minimum requirements for the MBBS course are 50\% marks in physics, chemistry, biology, and English in the ' $10+2$ ' examinations (For reserved category students, the requirement is $40 \%$.). The admission requirements differ across universities. Generally, students who attain higher marks in the qualifying examinations and in the medical entrance examinations conducted by various agencies are accepted onto the MBBS course. But, the irony is, rampant growth of the medical colleges in the private sector has created now new dimension of challenges. The donation-based seats given in private medical colleges are facing heavy criticism, because this makes India the only country for authorizing the sale of medical seats by private medical colleges, accepting the principle that the ability to pay, and not on the basis of merit, is seriously affecting quality of Indian health care system. ${ }^{[22]}$ Though government of India has policy in favor of growth of the private sector in medical education, the real issue of development of competencies and the process by which the reasonable number of each category of health care providers is produced and equipped with the knowledge, skills, and attitudes is 1 of the 3 main processes which influence performance of the health workforce including MBBS students as suggested by Dussault G. ${ }^{[23]}$ So, the quality of medical and health care services imparted by these private medical college students is also a very big challenge for Indian health care system.

\section{Issue of quality of medical education imparted by private medical colleges}

One of the tough challenge is to provide quality of education with optimum standards set by Medical Council of India (MCI). The content and training of medical education also varies from states to states and from government and private Institutions. National and state level guidelines are not available for teaching, and as a result, they are not exposed to recent changes in the program and policies. ${ }^{[15]}$ Due to lucrative clinical and diagnostic specialty, candidates opting for public health and para-clinical subjects are gradually declining, leading to again acute shortage of medical faculties, especially in anatomy, pharmacology, forensic medicine, and community medicine. ${ }^{[8]}$ This shortage sets a vicious cycle for compromised quality of medical education due to lack of appropriate mentorship. Another factor which makes the situation even more complex is the mobilization of the trained doctors to the rich countries under active International recruitment of doctor and nurses (Mode 4 of GTS agreement). According to WHO, about 100,000 doctors of Indian origin are settled in USA and UK alone. ${ }^{[24]}$ This is further creating a gap in generating the pool of available health workforce, which will deliver the services in India.

\section{Issue of infrastructural deficiencies in private medical colleges}

With the increasing number of medical colleges in the country, 20-30 percent of private medical colleges are good and rest 60-70 percent are not up to the medical standards i.e. quality of today's doctors is "not ideal and not very good" while considering PPP model for affordable healthcare. ${ }^{[20]}$ Insufficiency is in terms of infrastructure and clinical material to teach the medical graduates and postgraduates and thereby insufficient professional knowledge and poor competencies will definitely affect the quality of care that they will provide. It is a serious concern for the cohort of future specialized health professional to replace the existing one. Another emerging challenge in this field is the accreditation of the established and newly establishing medical college in terms of infrastructure, clinical material, trained and regular faculty, and admission process. In their study by Supe A, Burdick $\mathrm{WP}^{[13]}$ also recommended in-depth accreditation process for medical colleges used by the National Accreditation and Assessment Council, which is currently applied to only $10 \%$ of medical colleges, as well as reforms in curriculum, student selection, and internship assessment, in addition to stronger faculty-development efforts.

\section{Health economics: Rising cost of medical care and medical education}

Although Government of India (GOI) is committed to provide quality family welfare and health services to its population at affordable cost and easily accessible distance, nearly $72 \%$ of total health expenditure is born out of pocket by the household, and $3.2 \%$ families go in the cycle of financial burden due to expenditure on health. ${ }^{[25-27]}$ Out of the total expenditure by MOHFW, a significant percentage of 95.5 is given to allopathic system of medicine and only $4 \%$ towards Indian system of medicine. ${ }^{[28]}$ Public sector health care services utilization in India is low. ${ }^{[29,30]}$ Reasons listed from various studies for this are: a) high absenteeism, b) poor quality of services, and d) long distances to travel. ${ }^{[31-33]}$ That's why privatization is affecting health and medical education in the same way, as areas of social and administrative reform and private and voluntary organizations with a hopeful important role in rising economic liberalization. ${ }^{[34]}$ Now coinciding with falling public health investment, emergence of non-communicable diseases, and a spiraling demand, so there has been a steady growth in the corporatization of medical care.

Although government of India is spending an average 3 percent of GNP on education, in past, between 1950s and 1970s- spending for education was between 4.6 and 7.7 percent of total central government expenditures, but from 1980s, around 10 percent of central and state funds went to education, a proportion well below the average of 79 other developing countries, but total expenditure per student per year by the central and state governments has actually declined in real terms. ${ }^{[35]}$ There is also a buge disparity in costs and fees of government-run medical colleges e.g. each student costs the All India Institute of Medical Sciences (Under GOI), Delhi, around Rs 1.7 crore (Rs 31 lakh per year) while the fees paid by the student is only $R s$ 5,000/ year. ${ }^{[36]}$ 
Actually, Government of India (GOI) has steadily spent a revenue expenditure on medical education, training and research Rs 1078 million (in 1981) to 15757 (in 1999). An important area of public health expenditure which is dominantly the responsibility of the central government is medical training and research. Here too, the per capita spending has increased only slowly over the 1990s although recent years have shown some increase. However, it could be argued that this is an area where much greater public spending is required, and it must necessarily be undertaken by the central government.

Due to this reason, expansion of medical education by private sector has occurred, but is full of multiple challenges. One of the most prominent challenges is the average cost of education in a private vs. government medical college. The average cost of private medical education is around INR 40-50 lakhs, while in government sector, it is around INR 10,000-4 lakhs i.e. it is 10 times costlier in private medical colleges. ${ }^{[7]}$ So, medical education in a private institute is a very expensive affair and captures only that segment of the youth who can afford it. This is indirectly promoting the commoditization of the medical education.

So, what is happening is selling of the post-graduate medical seats in Crores of rupees to those who can afford to pay the private institutions rather than given as per their aptitude and performance for the medical branch. This enormous profit motive on the part of private management can ruin quality of medical education in India and Indian health system in long run. ${ }^{[37]}$

\section{CONCLUSION}

\section{Medical education privatization- An issue which needs a rethinking}

Medical education directly affects our "Right to Health," so its quality maintenance is a critical issue for our Indian health care system. Our Indian medical education system is one of the largest in the world, and medical colleges in India have rapidly proliferated in last 25 years, doubling since 1980 to currently 350 plus. With an increase in the number of approved private medical colleges and the increase in the number of seats recently, approximately 45,000 graduates are passing out every year from these colleges, from which $90 \%$ are privately-run. So, there is an urgent need for establishment of institute of health sciences in all states, especially in high focus states, which can ensure uniformity in admission, curriculum, and accreditation for all degrees in medical, nursing, and other para-medical courses. The growth of medical colleges in India is due to the large-scale privatization of medical education and lack of government control over medical education. One side of the coin shows that medical colleges are budding quickly, but the other side highlights acute shortage of faculties, which makes the environment irony to grow. No doubt, medical education in India has expanded in the last 60 years, but it continues to remain inadequate given the needs of the country. At this juncture, what we can conclude is that although privatization is a powerful tool to support public health system to increase accessibility and affordability of the health care at low opportunity cost, at the same time, it should be monitored with stringent implementation of the rules set by Medical Council of India so that health of the nation could not be compromised in the long run in search of appropriate health force with adequate skill mix. So, we say that, further studies for a better Indian health care system are urgently required either by Medical Council of India (MCI) itself or think tank agencies of government of India like National Institute of Health and Family Welfare (NIHFW) or All India Institute of Medical Sciences (AIIMS) on this critical issue.

\section{REFERENCES}

1. Vision 2015. [MCl Booklet. $2011 \mathrm{March}$ ]. Available from: http://www. mciindia.org/tools/announcement/MCl_booklet.pdf. [Last accessed on 2013 Aug 15].

2. Nandan D, Agarwal D. Editorial: Human resource for Health in India: Urgent need for reform. Indian J Community Med 2012;37:205-6.

3. Bajaj JS. Expert Review Committee Health Manpower Planning and development, U11010/2/86-MEP dated 8/5/1986. Ministry of Health and Family Welfare, New Delhi: Government of India; 1986.

4. Medical Council of India. Available from: http://www. mciindia.org/InformationDesk/MedicalCollegeHospitals/ ListofCollegesTeachingMBBS.aspx [Last accessed on $2013 \mathrm{Apr} 6$ ].

5. Savas ES. Privatization and Public-Private Partnerships. New York: Chatham House Publishers/Seven Bridges Press; 2000.

6. Shehnaz SI. Privatization of Medical Education. Sultan Qaboos Univ Med J 2010;10:6-11.

7. Times of India. Available from: http://timesofindia.indiatimes.com/home/ education/news/One-government-medical-college-seat-for-55000people/articleshow/21769867.cms. [Last accessed on 2013 Aug 12].

8. National Health Policy Document, New Delhi, 2000. Govt. of India. Ministry of Health and Family Welfare. Eleventh Five Year Plan 20072012. Planning Commission, Govt. of India, New Delhi.

9. Baru RV. Privatization and Corporatization. Seminar 489, May, 2000. Available from: http://www.india-seminar.com/2000/489/489percent20baru. $\mathrm{htm}$. [Last accessed on 2012 April 30].

10. Chakraborty S. Private Health Provision in Uttar Pradesh, India. In: Yazbeckand AS, Peters DH, editors. Health Policy Research in South Asia: Building Capacity for Reform. Washington DC: World Bank; 2003. p. 257-77.

11. $\mathrm{MCl}$ for relaxation of norms for setting up medical college. Zeenews.com. Available from: http://zeenews.india.com/news/delhi/mci-for-relaxationof-norms-for-setting-up-medical-colleges_656030.html. [Last accessed on 2013 Apr 6].

12. Times of India. Availablefrom: http://articles.timesofindia.indiatimes com/2013-08-05/india/41091925_1_screening-test-foreign-medicalgraduates-indian-students. [Last accessed on 2013 Aug 10].

13. Supe A, Burdick WP. Challenges and issues in medical education in India. Acad Med 2006;81:1076-80.

14. Sarda. Privatize Medical Education to ensure health for All. Accessed from: http://www.dnaindia.com/india/1595136/report-privatise-medical-educationto-ensure-health-to-all-delhi-high-court [Last accessed on 2013 Jun 7].

15. Nandan D, Nair KS, Datta U. Human Resources for public Health in India: Issues and Challenges. Health and Population : Perspectives and Issues 2007;30:230-42.

16. Shodhganga. Available from: http://www.shodhganga.inflibnet.ac.in/ bitstream/10603/854/16/16_chapter\%208.pdf. [Last accessed on 2013 Aug 15].

17. Rao K, Bhatnagar A, Berman P. India's health workforce: Size, composition and distribution. In: La Forgia J, Rao K, editors. India Health Beat. New Delhi: World Bank, New Delhi and Public Health Foundation of India; 2009.

18. Narayana KV. Changing Health Care System. Econ Polit Wkly 2003;1230-41. 
19. Ananthakrishnan N. Acute shortage of teachers in Medical Colleges: Existing problems and possible solutions. Natl Med J India 2007;20:25-9.

20. Trehan N. PPP model for affordable healthcare. The Economic times, PTI, Jan 19, 2013, 09.17PMIST. Available from: http://articles. economictimes.indiatimes.com/2013-01-19/news/36432126_1_medicalcolleges-ppp-model-bad-quality. [Last accessed on 2013 Apr 13].

21. Privatization of medical education and its worst effects. IMA A.P State. Accessed from: http://imaapstate.blogspot.in/2010/05/privatization-ofmedical-education-and.html. [Last accessed on 2013 Apr 12].

22. Rao S. Doctors by merit, not privilege. The Hindu, 2013 June 26.

23. Dussault G. Human Resources Development: The Challenge of Health Sector Reform, Human Development, Latin America and the Caribbean Region, The World Bank, 1999.

24. World Health Organization 2006, Working together for Health, World Health Report, 2006.

25. National Health Accounts Cell, Ministry of Health and Family Welfare, Government of India; 2005. National Health Accounts India. Available from: http://planningcommission.nic.in/reports/genrep/health/National_ Health_Account_04_05.pdf. [Last accessed on 2013 May 6].

26. Doorslaer VE, O'Donnell O, Rannan RP, Somanathan A, Adhikari $\mathrm{SR}$, Garg CC, et al. Effect of payments for health care on poverty estimates in 11 countries in Asia: An analysis of household survey data. Lancet 2006;368:1357-64.

27. Prinja S, Kanavos P, Kumar R. Health care inequities in north India: Role of public sector in universalizing health care. Indian $\mathrm{J}$ Med Res 2012;136:421-31.

28. National Health accounts India: Report 2001-02. Available from: http://siteresources.worldbank.org/INTHSD/Resources/3762781261143298590/6660179-1280173228245/India2001_02.pdf [Last accessed on 2013 Aug 15].
29. Levesque JF, Haddad S, Narayana D, Fournier P. Outpatient care utilization in urban-Kerala, India. Health Policy Plan 2006;21:289-301.

30. Vaishnavi SD, Dash U. Castastrophic payments for care among households in urban Tamil Nadu, India. J Int Dev 2009;21:169-84.

31. Hammer J, Aiyar Y, Samji S. Understanding government failure in public health services. Econ Polit Wkly 2007;42:4049-59.

32. Gupta I, Dasgupta P. Health-seeking behaviour in urban Delhi: An exploratory study. World Health Popul 2000;3.

33. Sengupta A, Nundy S. The private sector in India. BMJ 2005;331:1157-8.

34. Joy S, Ravindran, Rekha M, Vijayan, Dr. Shibu and Ugargol AP, et al. Mushrooming of Private Medical Schools in India, the Present Student Profile and Cost of Medical Education and its Impact on Equity, Health Care Accessibility, Cost and Perceived Quality of Health Care. IHEA 2007 6th World Congress: Explorations in Health Economics Paper. Available from: SSRN: http://ssrn.com/abstract=992143. [Last accessed on 2013 Sep15].

35. Country Studies. India Table of contents. Available from: http:// countrystudies.us/india/37.htm [Last accessed on 2013 Aug 15].

36. Why-a-Lucknow-degree-costs-the-same-as-a-Harvard degree. Available from: http://www.indiaspend.com/sectors/why-a-lucknow-degree- coststhe-same-as-a-harvard-degree. [Last accessed on 2013 Aug 15].

37. Das A. Medical PG seats being sold! The Conundrum of Privatized Medical Education. Indian J Med Res 2012;135:255-7.

How to cite this article: Davey S, Davey A, Srivastava A, Sharma P. Privatization of medical education in India: A health system dilemma. Int J Med Public Health 2014;4:17-22.

Source of Support: Nil, Conflict of Interest: None declared. 